\title{
SMALL BUSINESS AND ENTREPRENEURSHIP DEVELOPMENT - A MAIN CRITERIA OF THE COUNTRY'S ECONOMIC GROWTH
}

\author{
Arzimatov $B$. \\ master, \\ Kholmatov B. \\ supervisor \\ Fergana State University \\ Fergana, Uzbekistan
}

\begin{abstract}
Annotation. The article spoke about the ongoing reforms in the economic sphere in our country, the conditions created to support small business and entrepreneurship, the creation of a strong competitive environment.

Keywords: economy, small business, entrepreneurship, real income, socio-economic development, privileges, preferences, farming
\end{abstract}

\section{Introduction}

In recent years, in the process of large-scale reforms in the social and economic spheres and sectors in our country, special attention is paid to supporting small business and private entrepreneurship and creating more favorable conditions for them. Improving the living standards of the population, increasing real incomes and providing employment through the development of small business and private entrepreneurship is one of today's priorities.

Entrepreneurship development has been identified as an important direction in ensuring socio-economic development in Uzbekistan. The Action Strategy for the Development of the Country for 2017-2021 states that "systematic assistance from the state in the systematic improvement of a solid legislative and legal framework for the development of the industry, providing benefits and preferences for entrepreneurship, technical and technological re-equipment and modernization of production" [1 ] functions are shown. It is also necessary to radically improve the material conditions of the population in order to create conditions for entrepreneurship and a stable source of income for each family, to ensure significant positive changes in the quality and standard of living; ensuring comprehensive support of entrepreneurial initiatives of the population, systematic practical assistance in the organization and implementation of entrepreneurial activities; to teach entrepreneurship skills to the population and provide practical assistance in organizing the relevant activities; creating additional jobs and income opportunities; establishment of mini-clusters in families who have started new business activities in the mahallas; construction of market infrastructure facilities, service outlets and other measures are being taken. to teach entrepreneurship skills to the population and provide practical assistance in organizing the relevant activities; creating additional jobs and income opportunities; establishment of mini-clusters in families who have started new business activities in the mahallas; construction of market infrastructure facilities, service outlets and other measures are being taken. to teach entrepreneurship skills to the population and provide practical assistance in organizing the relevant activities; creating additional jobs and income opportunities; establishment of mini-clusters in families who have started new business activities in the mahallas; construction of market infrastructure facilities, service outlets and other measures are being taken.

Over the past two and a half years, more than fifty decrees and resolutions of the President of the Republic of Uzbekistan have been adopted to support small business and private entrepreneurship in the development of the economy, employment and income. In particular, the procedures for state registration of business activities, obtaining various permits and many other services have been simplified. To facilitate this, the Public Service Agency and its local centers have been established. The position of Representative (Business Ombudsman) for the protection of the rights and legitimate interests of business entities was introduced.The competitiveness of the national economy in these reforms also depends on the high share of small business and private entrepreneurship in the indicators of economic activity and its results.

The ability to create new jobs at low cost, rapid flexibility in the market segment, especially in the service sector, and the achievement of results at the expense of small financial resources show the importance of small business development. Therefore, the issue of rapid development of small business and private entrepreneurship in our country is inextricably linked with the localization of production, development of services, as well as increasing the export potential of the country. If we pay attention to the processes of state support of small business and private entrepreneurship, today all the conditions for the activities of these entities have been created, including

First, it quickly adapts to the necessary conditions of a market economy, ensuring its high efficiency as a result of deep specialization and cooperation. Second, it is characterized by a high level of access to the market of goods and services needed by the population, taking into account the balance of supply and demand in the market. Third, it offers cheap and quality goods and services to consumers by creating a competitive environment. Fourth, the market economy creates an entrepreneurial environment and spirit that would not exist without it [2].

Another important aspect of small business and private entrepreneurship is that in a highly competitive environment they are constantly forced to develop and have to adapt to current market conditions, their superiority over other business 
entities is a source of increase in their profits. After all, a market economy requires everyone to be in constant motion so that people can live the way they want to live.

In order to reliably protect the interests of small business and private entrepreneurship in our country, to ensure their further development, the Decree of the President of the Republic of Uzbekistan dated February 7, 2017 "On Strategy for further development of the Republic of Uzbekistan" as well as covering the socio-economic life of the country, has shown the need for a systematic, critical and comprehensive approach to the development of small business and private entrepreneurship. The role of small business and private entrepreneurship in the implementation of each of the five priorities of the Action Strategy is extremely unique. Including,

- Ensuring the balance and stability of the national economy, increasing the share of industry, services, small business and private entrepreneurship;

- Stimulation and development of diversified farms, primarily engaged in the production, processing, preparation, storage, sale, construction and provision of agricultural products creating favorable conditions for;

- Ensuring reliable protection of the rights and guarantees of private property, overcoming all kinds of barriers and restrictions, full freedom in the development of private entrepreneurship and small business, in practice, "If the people are rich, the state is rich and will be strong";

- creation of a favorable business environment for the broad development of small business and private entrepreneurship, strict prevention of illegal interference of state, regulatory and law enforcement agencies in the activities of business structures.

For the development of small business and private entrepreneurship in the Republic and its regions, it is expedient to take the following measures and strictly control their implementation:

- Strict control over the absence of artificial barriers in the use of benefits and privileges provided to entrepreneurs;

- increase access to not only domestic credit lines, but also external credit lines to support the investment activities of entrepreneurs;

- Development of mechanisms for financing investment projects;

- development of local forms of entrepreneurship based on the natural features and opportunities of the places;

- Revitalization of the views of the rural population on entrepreneurship through the development of services in rural areas;

- Introduction of guarantees for obtaining loans from commercial banks for the implementation of business projects through guarantee funds;

- Further reduction of lending rates allocated by commercial banks for business modernization.

In short, the development of small business and private entrepreneurship is in the interests not only of the country's economy, but also of every citizen, and the implementation of the above measures will contribute to the further development of small business and private entrepreneurship in the economy.

\section{REFERENCES:}

1. Decree of the President of the Republic of Uzbekistan dated February 7, 2017 "On the strategy of actions for further development of the Republic of Uzbekistan."

2. S.S.G'ulomov. "Entrepreneurship and small business". - T .: Sharq Publishing and Printing Joint-Stock Company. Editor-in-Chief. 2002. - 369 pages.

3. Rube AND Financial Business: History, Theory, Practice. - M .: «TEIS», 2000.

4. Mashirova TN, Sabenova BN, Sixymbekova AM Osnovnye napravleniya razvitiya malogo i srednego biznesa: zarubejnyy opyt. // J. Economics and finance. №3. 2012. S. 31.

5. KHOLMATOV, B. A. (2020). DEVELOPMENT OF THE SAVING FACTOR IN THE AGRICULTURE OF UZBEKISTAN. THE AMERICAN JOURNAL OF MANAGEMENT AND ECONOMICS INNOVATIONS, 2(12), 2326.

6. Mirzarahimov, B. H. (2020). The Tasks Of Tourism In Aesthetic Education: The Harmony Of Historicity And Modernity. The American Journal of Social Science and Education Innovations,2(09), 652-658.

7. Mirzarahimov, B. (2019). The factor of good neighborhood and tourism development (Philosophical analysis). Scientific Bulletin of Namangan State University, 1(1), 140-145.

8. Mirzarakhimov, В. (2020). Tourism-is a modern means of aesthetic education. СБОРНИК СТАТЕЙ.

9. Madimarovna, A. I., \& Khoshimovich, M. B. (2020). Factors for the development of tourism culture in the uzbek national value system. ACADEMICIA: An International Multidisciplinary Research Journal,10(4), 575-580.

10. Madimarovna, A. I. (2020). The Role of Art in Youth's Aesthetic Education. Cross-Cultural Communication, 16(1), 121-123.

11. Arzimatova, I. (2019). Art industry development of society and society culture. Scientific Bulletin of Namangan State University,1(1), 129-134.

12. Arzimatova, I. (2019). AESTHETIC EDUCATION, ITS FEATURES AND STRUCTURE. Scientific Bulletin of Namangan State University, 1(6), 219-222. 
13. Арзиматова, И. М. (2020). Искусство как своеобразное средство воспитания. Вестник педагогики: наука и практика, (51), 116-117.

14. АРЗИМАТОВА, И., \& МУМИНОВ, Ж. (2019). РОЛЬ И ЗНАЧЕНИЕ ЭСТЕТИЧЕСКОЙ МОРАЛИ В ПРОЦЕССЕ СОВЕРШЕНСТВОВАНИЯ МОЛОДОГО ПОКОЛЕНИЯ. ББК 60 О 23, 60.

15. АРЗИМАТОВА, И., \& МУМИНОВ, Ж. (2019). СЕКЦИЯ «ФИЛОСОФСКИЕ НАУКИ». ББК 60 А 43, 234.

16. Арзиматова, И. М. (2016). К вопросу о созидательном потенциале национальной эстетической культуры в гражданском обществе. Молодой ученый, (3), 1112-1114.

17. Madimarovna, A. I. (2020). The Role of Art in Youth's Aesthetic Education. Cross-Cultural Communication, 16(1), 121-123.

18. Arzimatova, I. (2019). Art industry development of society and society culture. Scientific Bulletin of Namangan State University,1(1), 129-134.

19. Arzimatova, I. (2019). AESTHETIC EDUCATION, ITS FEATURES AND STRUCTURE. Scientific Bulletin of Namangan State University, 1(6), 219-222. 